\title{
OPEN Increased planting density combined with reduced nitrogen rate to achieve high yield in maize
}

\author{
Xiangbei Du ${ }^{\bowtie}$, Zhi Wang, Weixia Lei \& Lingcong Kong
}

The combination effects of nitrogen $(\mathrm{N})$ fertilizer and planting density on maize yield, $\mathrm{N}$ use efficiency and the characteristics of canopy radiation capture and radiation use efficiency are not well documented in the Huanghuaihai Plain region in China. A 2-year field experiment was conducted from 2017 to 2018 in a split plot design with two $\mathrm{N}$ levels $\left(240\right.$ and $204 \mathrm{~kg} \mathrm{~N} \mathrm{ha}^{-1}$ ) applied to main plots and three plant densities $\left(67,500,77,625\right.$ and 87,750 plants ha $\left.^{-1}\right)$ allocated to sub plots. Our results show that a $30 \%$ greater plant density combined with a $15 \%$ lower $\mathrm{N}$ rate (basal $\mathrm{N}$ ) enhanced $\mathrm{N}$ partial factor productivity (NPFP) by $24.7 \%$ and maize grain yield by $6.6 \%$ compared with those of the conventional high $\mathrm{N}$ rate combined with a low density planting management practice. The yield increase was mainly attributed to significantly increased kernel numbers and biomass. The increased intercepted photosynthetically active radiation (IPAR) was the primary factor responsible for the high productivity of maize at increased planting density under reduced $\mathrm{N}$ conditions. The results indicate that increase planting density with reduced basal $\mathrm{N}$ application might benefit maize cropping for achieving high yields and sustainable development of agriculture.

Maize (Zea mays L.) is a major staple crop species and accounts for $60 \%$ of global human consumption, livestock feed and raw materials for industrial purposes ${ }^{1,2}$. Nitrogen $(\mathrm{N})$ is a key element for maize yield ${ }^{3,4}$. Previous studies have shown that increasing $\mathrm{N}$ application rate is important way to obtain high grain yield ${ }^{5,6}$. However, excessive fertilization is a severe problem that increases grain yield but reduces $\mathrm{N}$ use efficiency $(\mathrm{NUE})^{7-9}$, increases costs, and causes severe environmental pollution ${ }^{10,11}$. Improving fertilizer utilization, especially with higher $\mathrm{N}$ use efficiency, is one of the essential strategies to achieve the goals of sustainable agriculture ${ }^{12}$. In addition to nitrogen, planting density is another key factor in determining maize yield ${ }^{13-16}$. Previous studies have shown that increasing density is among the major factors associated with increases in maize grain yield ${ }^{13,17-21}$ and $\mathrm{N}$ use efficiency ${ }^{22,23}$. However, increased density also increases the plants competition for light and nutrients ${ }^{24}$.

Farmers in China frequently use more $\mathrm{N}$ fertilizer than necessary for high maize yields. However, this approach does not increase the grain yield and in fact actually reduce economic benefits ${ }^{25}$. Therefore, it is imperative to optimize fertilizer management during the maize growth period, which can not only reduce $\mathrm{N}$ input but also improve grain yield and environmental sustainability ${ }^{26,27}$. While increased density generally stimulates crop productivity ${ }^{28,29}$, reduced $\mathrm{N}$ often has the opposite effect on yield ${ }^{3,22}$. Previous studies have shown that densification may compensate for the negative effects of reduced $\mathrm{N}$ on crop productivity ${ }^{30}$. Therefore, a reasonable increase of planting density and supplying adequate $\mathrm{N}$ application are important agronomic practices to increase maize grain yield.

Theoretically, maize yield depends on the total biomass accumulation and its partitioning to the grain. It is well known that biomass production is the product of intercepted photosynthetically active radiation (IPAR), which is a function of both canopy architecture and the leaf area index (LAI), that is converted into biomass (radiation use efficiency, (RUE) $)^{31}$. Previous studies have shown that plant density and $\mathrm{N}$ rates significantly affect canopy structure, leading to differences in the IPAR and RUE, which ultimately influence yield ${ }^{28,32}$. Greater yields associated with maize under different $\mathrm{N}$ rate and planting density can result from greater IPAR, RUE, or a combination of the two ${ }^{33}$. Previous studies has suggested that planting density and $\mathrm{N}$ application rate interact to obtain high grain yield and NUE ${ }^{5,6,17,25}$. However, to our knowledge, the combined effects of planting density with $\mathrm{N}$ application rate on maize canopy development and radiation capture and use efficiency use are not well documented.

Our objectives are to develop an optimum combination of an appropriate $\mathrm{N}$ rate and planting density aimed at achieving high yields with reduced inputs for environmentally friendly maize cropping. Thus, a 2 -year field 


\begin{tabular}{|c|c|c|c|c|c|c|c|c|}
\hline Year & Planting treatments & Ear number $\left(\mathrm{ha}^{-1}\right)$ & Number of seed per ear & kernel number $\left(\mathbf{m}^{2}\right)$ & $\begin{array}{l}\text { Thousand-kernel weight } \\
\text { (g) }\end{array}$ & Yield $\left(\mathrm{t} \mathrm{ha}^{-1}\right)$ & Biomass $\left(\mathrm{t} \mathrm{ha}^{-1}\right)$ & HI \\
\hline \multirow{10}{*}{2017} & N1D1(CK) & $59,448.3 \mathrm{~b}$ & $456.3 \mathrm{a}$ & $2712.6 \mathrm{bc}$ & $319.4 \mathrm{a}$ & $8.6 \mathrm{ab}$ & $14.2 \mathrm{bc}$ & 0.52 \\
\hline & N1D2 & $64,243.5 \mathrm{ab}$ & $438.2 \mathrm{ab}$ & $2815.2 \mathrm{ab}$ & 317.1a & $8.9 \mathrm{a}$ & $15.0 \mathrm{ab}$ & 0.51 \\
\hline & N1D3 & $70,141.7 \mathrm{a}$ & $420.4 \mathrm{~b}$ & $2948.8 \mathrm{a}$ & $308.5 \mathrm{~b}$ & $9.2 \mathrm{a}$ & $15.6 \mathrm{a}$ & $0.51 a$ \\
\hline & N2D1 & $58,523.3 \mathrm{~b}$ & $445.2 \mathrm{a}$ & $2605.5 c$ & $315.8 \mathrm{ab}$ & $8.2 \mathrm{~b}$ & $13.4 \mathrm{c}$ & $0.53 a$ \\
\hline & N2D2 & $63,546.2 \mathrm{ab}$ & $432.5 \mathrm{ab}$ & 2748.4ab & $311.8 \mathrm{ab}$ & $8.7 \mathrm{ab}$ & $14.2 \mathrm{bc}$ & $0.53 a$ \\
\hline & N2D3 & $69,937.5 \mathrm{a}$ & $421.9 \mathrm{~b}$ & $2950.7 \mathrm{a}$ & $306.2 \mathrm{~b}$ & 9.1a & $15.2 \mathrm{a}$ & $0.52 a$ \\
\hline & \multicolumn{8}{|l|}{ Analysis of variance } \\
\hline & $\mathrm{N}$ rate $(\mathrm{N})$ & ns & ns & ns & ns & * & ns & ns \\
\hline & Density (D) & $* *$ & * & $* *$ & ns & * & $* *$ & ns \\
\hline & $\mathrm{N}^{*} \mathrm{D}$ & * & * & * & * & * & $*$ & ns \\
\hline \multirow{10}{*}{2018} & N1D1(CK) & $63,897.5 \mathrm{~b}$ & $454.9 \mathrm{a}$ & $2906.7 b c$ & $320.8 \mathrm{a}$ & $9.2 \mathrm{ab}$ & $15.9 \mathrm{~b}$ & $0.50 \mathrm{a}$ \\
\hline & N1D2 & 69,956.1ab & $442.1 \mathrm{ab}$ & 3092.8ab & $315.6 \mathrm{ab}$ & $9.7 \mathrm{ab}$ & $16.5 \mathrm{ab}$ & $0.51 a$ \\
\hline & N1D3 & $74,921.7 \mathrm{a}$ & $432.6 \mathrm{~b}$ & $3241.1 \mathrm{a}$ & $310.1 \mathrm{~b}$ & $10.2 \mathrm{a}$ & $16.9 \mathrm{a}$ & $0.52 a$ \\
\hline & N2D1 & $62,245.2 \mathrm{~b}$ & $446.6 \mathrm{a}$ & $2779.9 \mathrm{c}$ & 318.1ab & $8.8 \mathrm{~b}$ & $14.9 \mathrm{c}$ & $0.51 a$ \\
\hline & N2D2 & $68,794.9 \mathrm{ab}$ & $437.8 \mathrm{ab}$ & 3011.8ab & $313.8 \mathrm{ab}$ & 9.4ab & $16.1 \mathrm{ab}$ & $0.50 \mathrm{a}$ \\
\hline & N2D3 & $73,969.2 \mathrm{a}$ & $430.5 \mathrm{~b}$ & $3184.4 \mathrm{a}$ & $309.9 \mathrm{~b}$ & $10.0 \mathrm{a}$ & $16.9 \mathrm{a}$ & $0.50 \mathrm{a}$ \\
\hline & \multicolumn{8}{|l|}{ Analysis of variance } \\
\hline & $\mathrm{N}$ rate $(\mathrm{N})$ & ns & ns & ns & ns & ns & ns & ns \\
\hline & Density (D) & $* *$ & * & $* *$ & ns & * & $* *$ & ns \\
\hline & $\mathrm{N}^{*} \mathrm{D}$ & * & * & * & * & * & * & ns \\
\hline
\end{tabular}

Table 1. Yield and yield components of maize in different planting treatments in 2017 and 2018. Values followed by different letters within a column are significantly different $(P<0.05)$. $H I$ harvest index, ns no significant effects. ${ }^{\star}$ Significant effects at $P<0.05$. ${ }^{\star}$ Significant effects at $P<0.01$.

experiment was conducted to determine the combined impacts of planting density and $\mathrm{N}$ rate on maize yield, NUE and the characteristics of canopy radiation capture and radiation use efficiency. We expect that the results will provide new insight for understanding the mechanisms underlying the establishment of high-yield and high-efficiency maize cultivation and provide guidance for future maize cropping practices.

\section{Results}

Grain yield and yield components. With the exceptions of thousand-kernel weight and the harvest index (HI), ear number, number of seeds per ear, kernel number, yield and biomass were significantly affected by planting density and its interactions with $\mathrm{N}$ rate in 2 years (Table 1). Higher productivity was observed in the high density treatments. The number of seeds per ear in the D2 and D3 treatments was lower than that in the D1 treatment, but the ear number significantly increased, resulting in an increased number of kernels per unit area. The yield and biomass of N1D3 treatments were the highest in the six treatments. The N1D2, N1D3, $\mathrm{N} 2 \mathrm{D} 1, \mathrm{~N} 2 \mathrm{D} 2$ and N2D3 treatments increased biomass by $4.8 \%, 7.3 \%,-4.3 \%, 1.0 \%$ and $6.0 \%$, respectively, and the grain yield increased by $4.7 \%, 8.1 \%,-6.0 \%, 0.7 \%$ and $6.6 \%$, respectively, compared to that in the CK, over two growing seasons.

Crop $\mathbf{N}$ uptake and $\mathbf{N}$ use efficiency. $\mathrm{N}$ uptake was significantly affected by density and its interactions with N rate both in 2017 and 2018, and NPFP was significantly affected by N rate and its interactions with density in 2 years (Table 2). Across both years, the N1D2, N1D3, N2D1, N2D2 and N2D3 treatments increased the N uptake by $4.3 \%, 9.4 \%,-4.2 \%, 0.6 \%$ and $8.1 \%$, respectively, and increased the NPFP by $4.8 \%, 7.3 \%, 12.6 \%, 18.9 \%$ and $24.7 \%$, respectively, compared to that of the CK (Fig. 1). There were no significant interactions in $\mathrm{N}$ harvest index (NHI) between planting treatments.

Canopy structural characteristics. As shown in Fig. 2, maize LAI increased dramatically during the initial growth stage, peaked at the same time and then declined with leaf senescence in all treatments. The LAI of maize was distinctly affected by density and its interactions with $\mathrm{N}$ rate both in 2017 and 2018, and a relatively high LAI was observed in the high density treatments (Table 2). Averaged over two years, the peak values of the LAI for the N1D2, N1D3, N2D1, N2D2 and N2D3 treatments were 5.7\%, 9.5\%, $-4.1 \%, 2.4 \%$ and $6.4 \%$ higher than the value of the CK, respectively.

Planting treatments also altered the vertical distribution of the maize LAI at the tasseling and silking stages (Fig. 3). There was little difference in the LAI of the middle and lower canopies among the six treatments. By contrast, marked differences were noted in the LAI of the upper and whole canopies among the six planting treatments. The LAI of the high density treatments increased for the upper and whole canopy but showed no significant difference for the middle and lower canopy compared to that in the CK. 


\begin{tabular}{|c|c|c|c|c|c|c|c|c|}
\hline Analysis of variance & N uptake & NPFP & NHI & $\mathbf{L A I}_{\max }$ & fPAR & IPAR & $k$ & RUE \\
\hline \multicolumn{9}{|l|}{2017} \\
\hline $\mathrm{N}$ rate $(\mathrm{N})$ & $\mathrm{ns}$ & $*$ & $\mathrm{~ns}$ & $\mathrm{~ns}$ & $\mathrm{~ns}$ & $\mathrm{~ns}$ & ns & $\mathrm{ns}$ \\
\hline Density (D) & $*$ & ns & ns & $\star *$ & $*$ & $*$ & ns & ns \\
\hline $\mathrm{N}^{*} \mathrm{D}$ & * & * & ns & * & $*$ & * & * & $*$ \\
\hline \multicolumn{9}{|l|}{2018} \\
\hline $\mathrm{N}$ rate $(\mathrm{N})$ & * & * & ns & ns & ns & ns & ns & ns \\
\hline Density (D) & $*$ & ns & ns & $*$ & $*$ & $*$ & ns & ns \\
\hline $\mathrm{N}^{\star} \mathrm{D}$ & $*$ & $*$ & ns & * & $*$ & $*$ & $*$ & * \\
\hline
\end{tabular}

Table 2. Variance analysis for the $\mathrm{N}$ rate and density and their interactions effect on $\mathrm{N}$ uptake and use efficiency, and radiation capture and use efficiency. NPFP N partial factor productivity, $N H I \mathrm{~N}$ harvest index, $L A I_{\max }$ maximum leaf area index, $P P A R$ fraction of PAR intercepted, IPAR cumulative intercepted PAR, $k$ light extinction coefficient, $R U E$ radiation use efficiency, $n s$ no significant effects. ${ }^{\star}$ Significant effects at $P<0.05$.

${ }^{*}$ Significant effects at $P<0.01$.
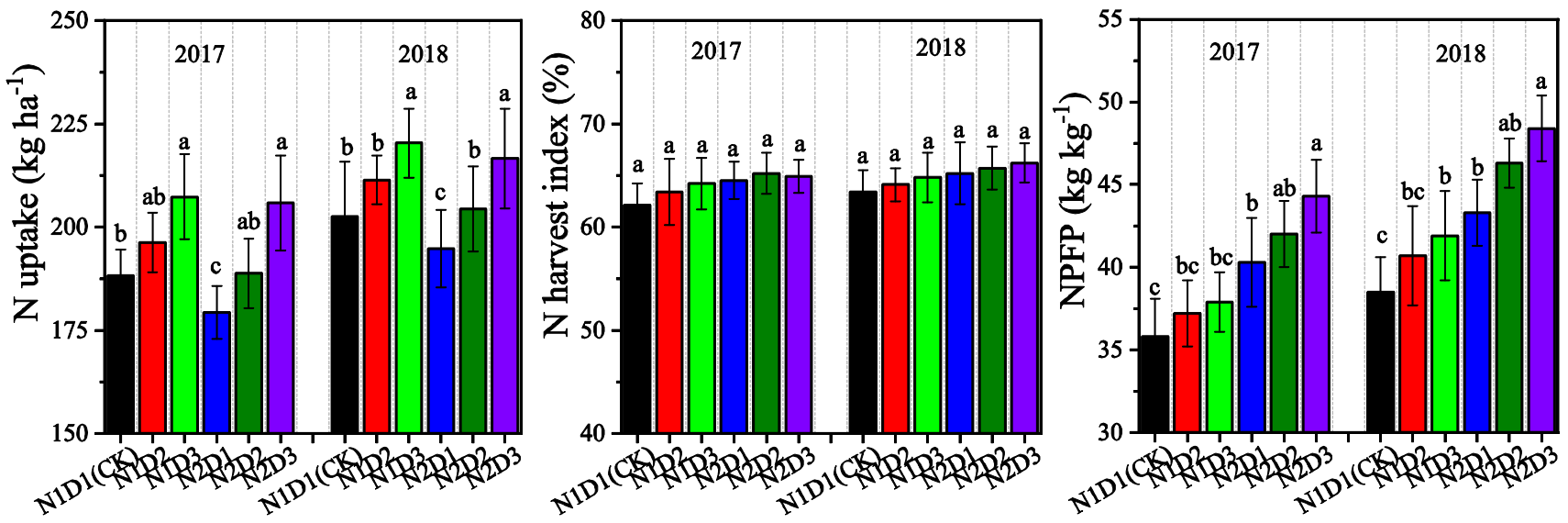

Figure 1. $\mathrm{N}$ uptake, $\mathrm{N}$ harvest index and $\mathrm{N}$ partial factor productivity of maize (NPFP) under different planting treatments in 2017 and 2018. Error bars indicate standard errors of replicates. Means followed by the same letter are not significantly different among different planting treatments at $P<0.05$.
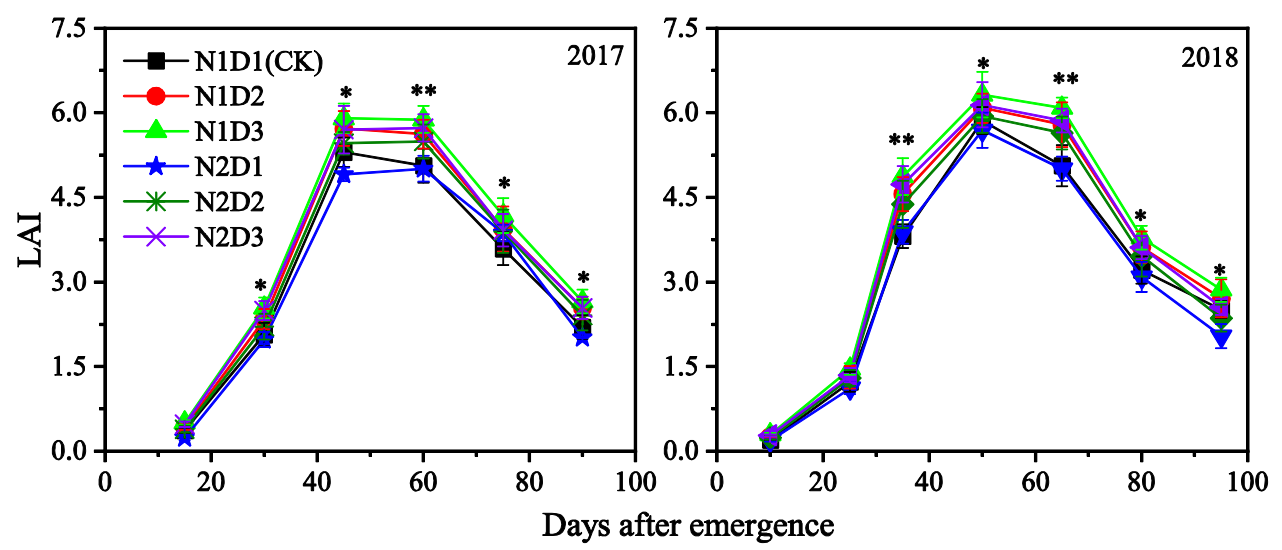

Figure 2. Maize leaf area index (LAI) trends during growing season as affected by planting treatments. Each data point is the mean \pm S.E. of three replications with ${ }^{*}$ and ${ }^{* *}$ are significant at $P<0.05$ and $P<0.01$, respectively. 


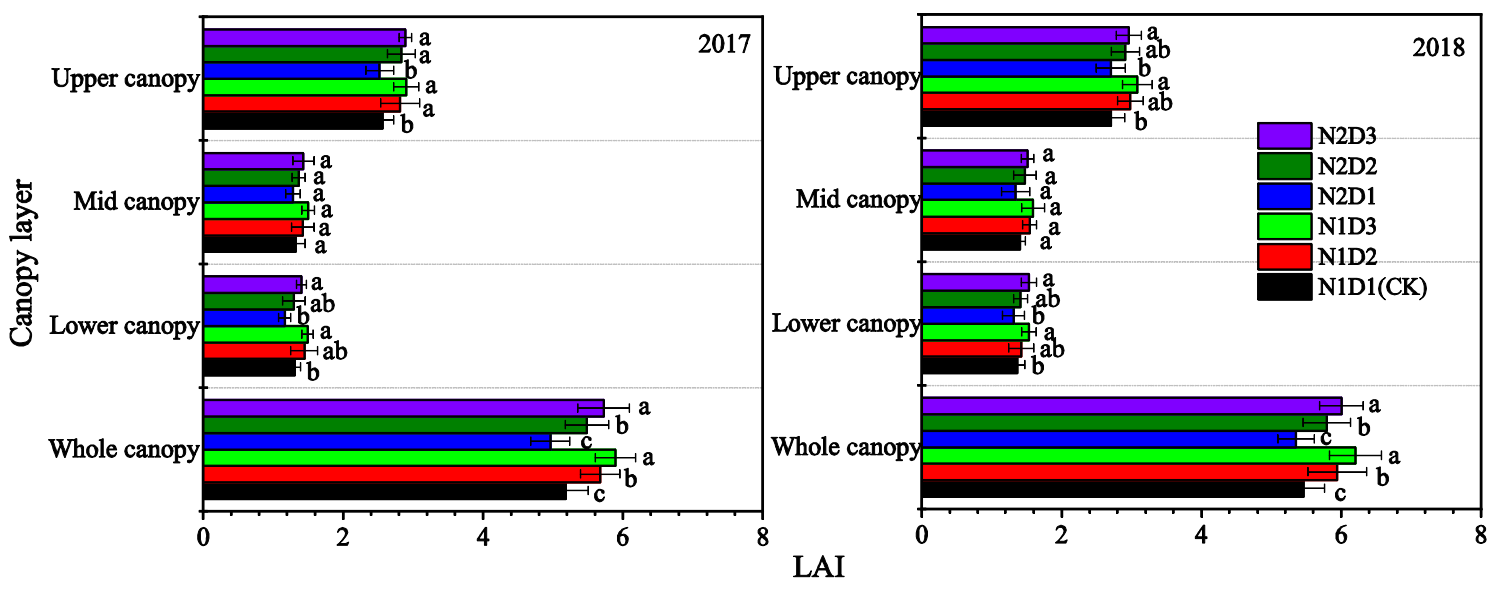

Figure 3. Vertical distribution of LAI in the canopy of maize in different planting treatments. The data were averaged measurements on 45 and 60 days after emergence (DAE), 2017 and 50 and 65 DAE, 2018. Upper canopy, middle canopy and lower canopy of maize mean top-two leaves above the ear leaf, the ear leaf and two leaves above and below it, and two leaves below the ear leaf-bottom leaf, respectively. Each data point is the mean \pm S.E. of three replications. Values followed by different letters within a column are significantly different $(P<0.05)$.
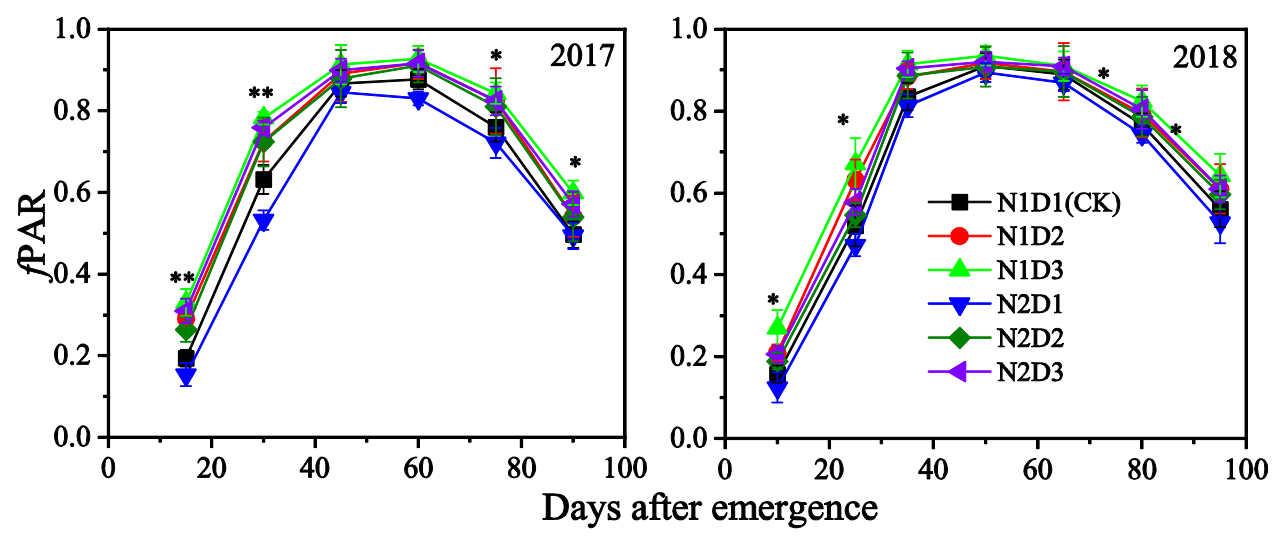

Figure 4. Changes in fraction of PAR intercepted ( $f \mathrm{PAR})$ by maize affected by planting treatments during the growing season. Each data point is the mean \pm S.E. of three replications with ${ }^{\star}$ and ${ }^{\star *}$ are significant at $P<0.05$ and $P<0.01$, respectively.

PAR interception. The fPAR of maize was distinctly affected by density and the interactions between density and $\mathrm{N}$ rate both in 2017 and 2018 (Table 2). The fPAR in the high density treatments had higher fPAR than that in the CK, throughout the growing season (Fig. 4). Compared to that of the CK, the mean fPAR of the N1D2, N1D3, N2D1, N2D2 and N2D3 treatments increased by $8.1 \%, 13.1 \%,-5.3 \%, 5.7 \%$ and $9.0 \%$, respectively, averaged over 2 years.

Planting treatments also had significant effects on the amount of PAR intercepted $\left(\mathrm{PAR}_{\mathrm{i}}\right)$ by the maize canopy (Fig. 5). The $\mathrm{PAR}_{\mathrm{i}}$ in the upper canopy decreased in the order of N1D3 $>$ N1D2 $>$ N2D3 $>$ N2D2 $>$ CK $>$ N2D1 for both years. In contrast, the $\mathrm{PAR}_{\mathrm{i}}$ in the lower canopy exhibited the opposite trend, with the order of N2D1 $>\mathrm{C}$ $\mathrm{K}>\mathrm{N} 2 \mathrm{D} 2>\mathrm{N} 2 \mathrm{D} 3>\mathrm{N} 1 \mathrm{D} 2>\mathrm{N} 1 \mathrm{D} 3$ for both years. Little difference in $\mathrm{PAR}_{\mathrm{i}}$ was detected in the middle canopy. The differences in the PAR captured by the maize canopy in the different planting treatments could be attributed to the PAR captured by the upper canopy. Compared to that for the CK, the whole-canopy PAR $_{\mathrm{i}}$ for the N1D2, N1D3, N2D1, N2D2 and N2D3 treatments were $4.6 \%, 8.3 \%,-3.0 \%, 1.0 \%$ and $5.4 \%$ greater, respectively, averaged across both years.

Canopy light extinction. There was a close exponential relationship between the fPAR and LAI of maize in the different planting treatments (Fig. 6). The extinction coefficient $(k)$ was notably affected by the interactions between density and $\mathrm{N}$ rate both in 2017 and 2018 (Table 2). The $k$ of the high density treatments were consistently higher than that of the CK across the two years. The equations depicted in Fig. 6 show that the $k$ values of the CK, N1D2, N1D3, N2D1, N2D2 and N2D3 treatments were $0.42,0.46,0.50,0.40,0.45$ and 0.46 , respectively, averaged over 2 years. 

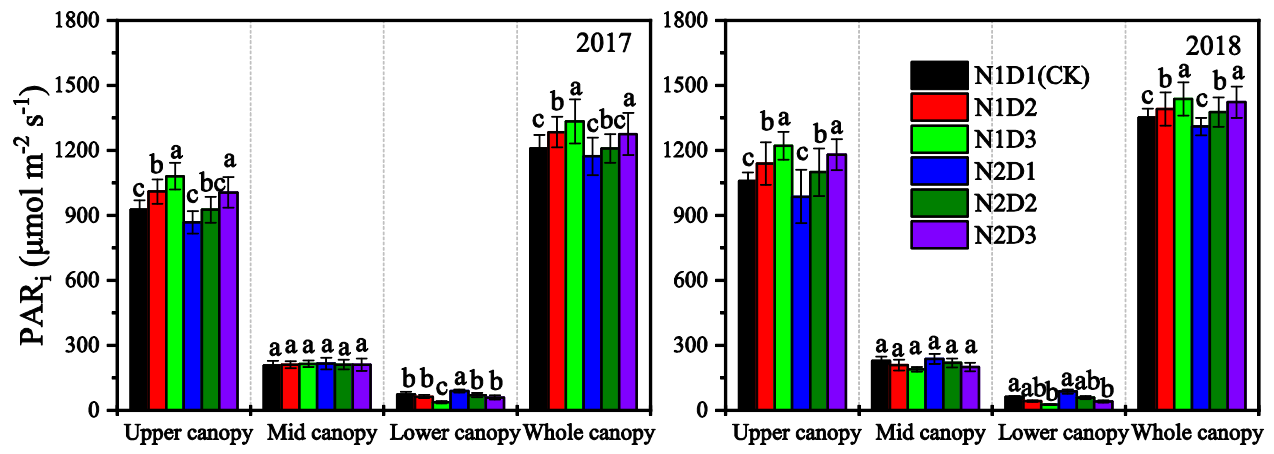

Canopy layer

Figure 5. Vertical distribution of incident $P A R$ intercepted $\left(\mathrm{PAR}_{\mathrm{i}}\right)$ under different planting treatments at tasseling and silking stage. The data were averaged measurements on 45 and 60 DAE, 2017 and 50 and 65 DAE, 2018. Upper canopy, middle canopy and lower canopy of maize mean top-two leaves above the ear leaf, the ear leaf and two leaves above and below it, and two leaves below the ear leaf-bottom leaf, respectively. Each data point is the mean \pm S.E. of three replications. Values followed by different letters within a column are significantly different $(P<0.05)$.
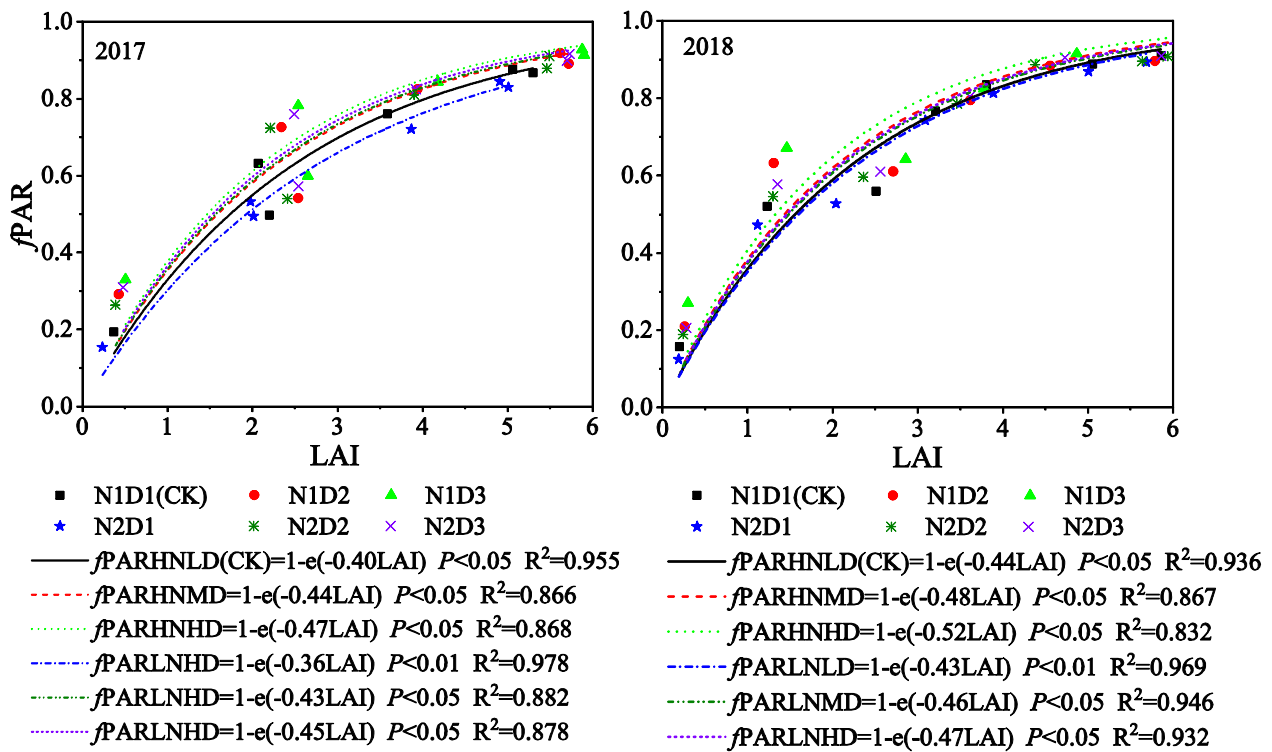

Figure 6. Relationship between the fractions of PAR intercepted (fPAR) and the leaf area index (LAI) of maize in different planting treatments.

Radiation capture and radiation use efficiency. The IPAR and RUE of maize were significantly affected by the interactions between density and N rate both in 2017 and 2018 (Table 2). The D2 and D3 treatments intercepted significantly more PAR than did the D1 treatments. Compared to that of the CK, the mean IPAR of the N1D2, N1D3, N2D1, N2D2 and N2D3 treatments increased by $6.2 \%, 14.3 \%,-4.9 \%, 4.2 \%$ and $12.4 \%$, respectively, averaged over 2 years (Table 3 ). The increased IPAR could be attributed to the significantly higher $f$ PAR throughout the maize growth period. The RUE of maize under the D3 treatments was consistently lower than that under the CK. When averaged over both years, the RUE values of the N1D2, N1D3, N2D1, N2D2 and N2D3 treatments were 1.4\%, 5.3\%, 1.2\%, 3.3\% and 5.1\% lower than the value of the CK, respectively.

Relationships between yield, $\mathrm{N}$ uptake and $\mathrm{N}$ use efficiency and radiation capture and radiation use efficiency. The relationships between the maize grain yield and yield components, $\mathrm{N}$ uptake and $\mathrm{N}$ use efficiency, and radiation capture and radiation use efficiency were investigated (Table 4). The data showed that the grain yield and biomass were significantly and positively correlated with the N uptake, LAI, fPAR and IPAR but were no correlated with the RUE. These correlations suggested that maize productivity was limited by the relatively low LAI leading to little fPAR and relatively low radiation capture. 


\begin{tabular}{|l|l|l|l|l|l|}
\hline Year & Planting treatments & IPAR $\left(\mathbf{M J ~ m}^{-2}\right)$ & $\triangle$ IPAR (\%) & RUE $\left(\mathbf{g ~ M J}^{-1}\right)$ & $\Delta$ RUE (\%) \\
\hline \multirow{5}{*}{2017} & N1D1 (CK) & $430.7 \mathrm{bc}$ & & $3.30 \mathrm{a}$ & \\
\cline { 2 - 6 } & N1D2 & $456.8 \mathrm{~b}$ & 6.06 & $3.28 \mathrm{a}$ & -0.53 \\
\cline { 2 - 6 } & N1D3 & $493.6 \mathrm{a}$ & 14.60 & $3.17 \mathrm{ab}$ & -3.97 \\
\cline { 2 - 6 } & N2D1 & $412.6 \mathrm{c}$ & -4.20 & $3.25 \mathrm{a}$ & -1.52 \\
\cline { 2 - 6 } & N2D2 & $445.1 \mathrm{~b}$ & 3.34 & $3.19 \mathrm{ab}$ & -3.16 \\
\cline { 2 - 6 } & N2D3 & $483.2 \mathrm{a}$ & 12.19 & $3.15 \mathrm{~b}$ & -4.40 \\
\hline \multirow{5}{*}{2018} & N1D1 (CK) & $465.5 \mathrm{bc}$ & & $3.42 \mathrm{a}$ & \\
\cline { 2 - 6 } & N1D2 & $495.2 \mathrm{c}$ & 6.38 & $3.34 \mathrm{ab}$ & -2.23 \\
\cline { 2 - 6 } & N1D3 & $530.4 \mathrm{a}$ & 13.94 & $3.19 \mathrm{~b}$ & -6.68 \\
\cline { 2 - 6 } & N2D1 & $439.9 \mathrm{c}$ & -5.50 & $3.39 \mathrm{ab}$ & -0.81 \\
\cline { 2 - 6 } & N2D2 & $488.5 \mathrm{~b}$ & 4.94 & $3.30 \mathrm{ab}$ & -3.49 \\
\cline { 2 - 6 } & N2D3 & $524.3 \mathrm{a}$ & 12.63 & $3.22 \mathrm{ab}$ & -5.87 \\
\hline
\end{tabular}

Table 3. Cumulative intercepted photosynthetically active radiation (IPAR), and radiation use efficiency (RUE) of maize in four planting treatments in 2017 and 2018. Values followed by different letters within a column are significantly different $(P<0.05) . \triangle I P A R$ and $\triangle R U E$ change of IPAR and RUE in the planting treatments in relation to the $\mathrm{CK}$.

\begin{tabular}{|c|c|c|c|c|c|c|c|c|c|c|c|c|}
\hline Index & Yield & Kernel number & Thousand kernels weight & Biomass & N uptake & NPFP & NHI & LAI & fPAR & IPAR & RUE & $\mathbf{k}$ \\
\hline Yield & 1.000 & & & & & & & & & & & \\
\hline Kernel number & $0.978^{\star *}$ & 1.000 & & & & & & & & & & \\
\hline Thousand kernels weight & -0.318 & -0.507 & 1.000 & & & & & & & & & \\
\hline Biomass & $0.987^{\star *}$ & $0.963^{\star *}$ & -0.307 & 1.000 & & & & & & & & \\
\hline $\mathrm{N}$ uptake & $0.961^{\star *}$ & $0.981^{\star *}$ & -0.491 & $0.968^{* *}$ & 1.000 & & & & & & & \\
\hline NPFP & 0.44 & 0.506 & -0.492 & 0.427 & 0.417 & 1.000 & & & & & & \\
\hline NHI & 0.349 & 0.442 & -0.576 & 0.345 & 0.354 & $0.927^{\star *}$ & 1.000 & & & & & \\
\hline LAI & $0.696^{\star}$ & $0.793^{\star *}$ & $-0.740^{\star *}$ & $0.684^{*}$ & $0.798^{* *}$ & 0.202 & 0.26 & 1.000 & & & & \\
\hline FPAR & $0.708^{\star *}$ & $0.790^{\star *}$ & $-0.679^{\star}$ & $0.722^{* *}$ & $0.821^{* *}$ & 0.197 & 0.244 & $0.964^{\star *}$ & 1.000 & & & \\
\hline IPAR & $0.941^{\star *}$ & $0.985^{\star *}$ & $-0.593^{\star}$ & $0.940^{* *}$ & $0.980^{* *}$ & 0.472 & 0.432 & $0.857^{\star \star}$ & $0.853^{* *}$ & 1.000 & & \\
\hline RUE & -0.028 & -0.221 & $0.890^{\star *}$ & 0.014 & -0.189 & -0.202 & -0.314 & $-0.626^{*}$ & -0.513 & -0.328 & 1.000 & \\
\hline $\mathrm{k}$ & $0.908^{* *}$ & $0.929^{* *}$ & -0.48 & $0.908^{* *}$ & $0.943^{* *}$ & 0.316 & 0.322 & $0.840^{* *}$ & $0.895^{\star \star}$ & $0.931^{* *}$ & -0.218 & 1.000 \\
\hline
\end{tabular}

Table 4. Correlation coefficients among maize yield, kernel number, thousand kernels weight, biomass, $\mathrm{N}$ uptake, $\mathrm{N}$ partial factor productivity (NPFP), $\mathrm{N}$ harvest index (NHI), leaf area index (LAI), mean fraction of PAR intercepted ( $f$ PAR), cumulative intercepted PAR (IPAR) and radiation use efficiency (RUE) for different planting treatments in 2017 and 2018. $\mathrm{n}=12, \mathrm{R}_{0.05}=0.576, \mathrm{R}_{0.01}=0.707$. ${ }^{\star}$ Significance of correlation at 0.05 level. ${ }^{* \star}$ Significance of correlation at 0.01 level.

\begin{tabular}{|l|l|l|l|l|l|l|}
\hline Meteorological data & Year & Jun & Jul & Aug & Sep & Total \\
\hline \multirow{2}{*}{ Rainfall $(\mathrm{mm})$} & 2017 & 80.1 & 130.0 & 260.7 & 283.5 & 754.3 \\
\cline { 2 - 7 } & 2018 & 210.1 & 189.3 & 271.4 & 31.9 & 702.7 \\
\hline $\begin{array}{l}\text { Average temperature } \\
\left({ }^{\circ} \mathrm{C}\right)\end{array}$ & 2017 & 25.3 & 29.7 & 27.1 & 22.4 & 26.1 \\
\cline { 2 - 7 } & 2018 & 26.2 & 28.7 & 28.4 & 23.2 & 26.6 \\
\hline \multirow{2}{*}{ PAR $\left(\mathrm{MJ} \mathrm{m}^{-2}\right)$} & 2017 & 259.9 & 297.7 & 234.0 & 180.3 & 971.9 \\
\cline { 2 - 7 } & 2018 & 277.4 & 270.6 & 244.2 & 191.5 & 983.8 \\
\hline
\end{tabular}

Table 5. Monthly rainfall, monthly photosynthetically active radiation (PAR) and daily average temperature at the experimental field in 2017 and 2018. PAR was estimated by multiplying solar radiation by 0.5 .

\section{Discussion}

Our results showed that reducing the $\mathrm{N}$ rate by $15 \%$ from 240 to $204 \mathrm{~kg} \mathrm{ha}^{-1}$ resulted in significantly increased grain yield (by 5.1-6.8\%) when combined with a $30 \%$ higher planting density (Table 1), which is consistent with the result of a previous study; the maize yield loss from reduced $\mathrm{N}$ input could be compensated by increased 


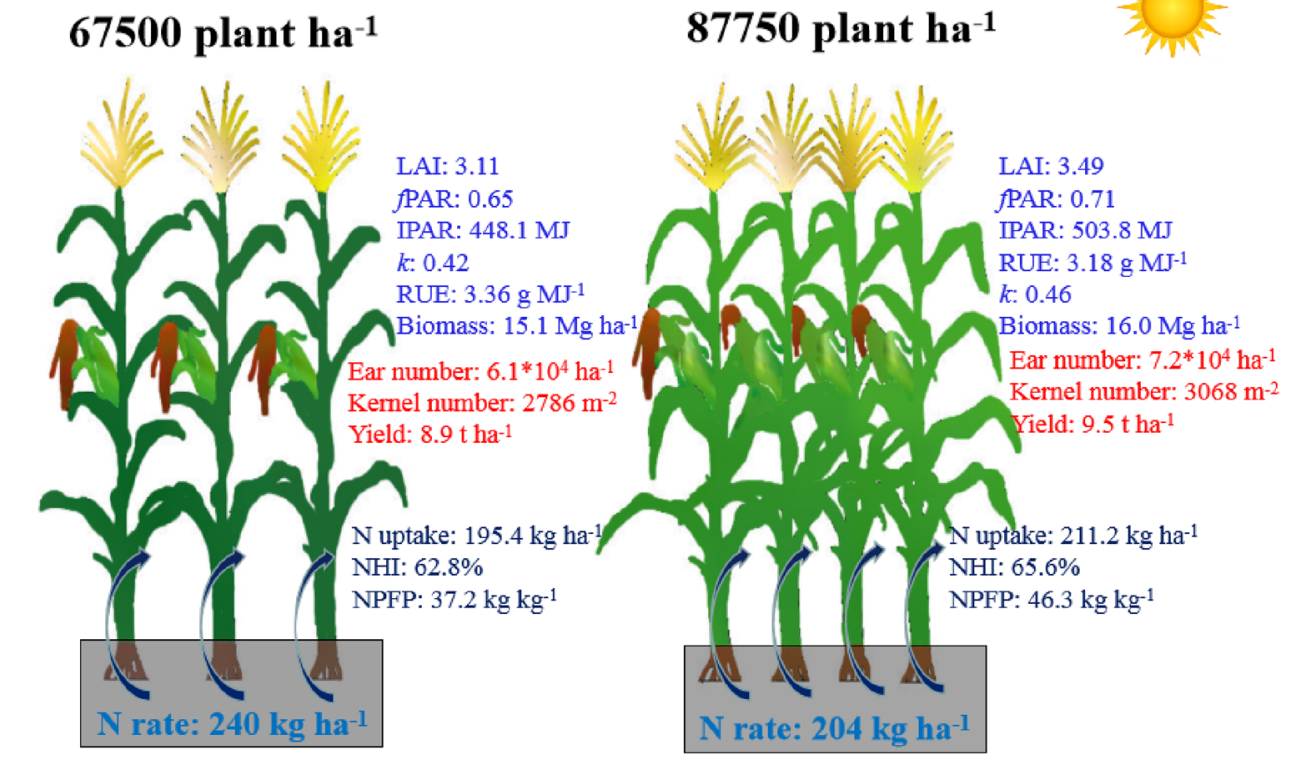

\section{0 plant ha-1}

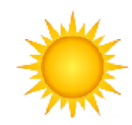

Figure 7. Schematic representation of the processes involved in the canopy development, radiation capture and radiation use efficiency, $\mathrm{N}$ uptake and $\mathrm{N}$ use efficiency and yield. All data in the figure were averaged by two experiment years. LAI leaf area index, $P$ PAR fraction of PAR intercepted, IPAR cumulative intercepted PAR, RUE radiation use efficiency, $k$ light extinction coefficient, $N H I \mathrm{~N}$ harvest index, NPFP N partial factor productivity.

density $^{5,14,34}$. We also found that increased planting density had positive effects on maize yield, with a relative yield increase of $3.8-8.8 \%$ recorded on the conventional high $\mathrm{N}$ rate.

Maize yield was determined by kernel number per unit area and thousand-kernel weight; the kernel number per unit area was considered the primary determinant ${ }^{35}$. In the present study, the increased yields in N2D3 treatments were mainly attributed to the increased kernel number. The results revealed that the $\mathrm{N}$ rate and density interaction significantly affected the kernel number and was strongly associated with yield (Table 4), which was consistent with the result of previous works ${ }^{13,19,23}$. For the high density treatments, a higher ear number could compensate for the negative effects of a lower kernel number per ear. As such, the kernel number increased by 9.6-10.6\%, which resulted in increased grain yields. Jiang et al. ${ }^{36}$ reported that for smaller groups, maize yield increased mainly because of increased ear numbers. It is worth noting that if only the $\mathrm{N}$ rate was reduced without increasing the planting density, the maize population might not be not large enough to achieve high yields (Table 1).

It is well known that crop yield formation depends on biomass accumulation and allocation to the grain. Numerous studies have demonstrated that yield increases could be achieved from enhanced biomass production, harvest index improvements or both ${ }^{23,30,37}$. In our study, there was an increase of $6.0-7.3 \%$ in the biomass in the N2D3 treatments compared to the CK, while the HI was generally unchanged (Table 1). The high yields in the N2D3 treatment were mainly derived from increased biomass accumulation (Fig. 7).

Biomass is the product of radiation intercepted by the canopy multiplied by the RUE. An increase in yield often results from increased radiation capture, more efficient use, or a combination of two ${ }^{38}$. The increased biomass production was almost exclusively caused by the increase in the IPAR (12.2-12.6\%) rather than changes in the RUE (decrease of 4.4-5.9\%) (Table 3). The results of our study demonstrated that the yield advantage of maize was mainly attributed to the increased IPAR. Our results corresponded with the typical explanations for increased grain yields at optimum density resulting from increased radiation interception ${ }^{39,40}$. This increased radiation capture during the critical period has been thought to be the primary reason for yield increases in many crops $^{41-43}$. The lower IPAR was the main reason that the whole-canopy photosynthetic capacity was weaker in conventional traditions maize planting practices used by farmer (Fig. 7).

The effects on radiation capture were explained by the improved maize canopy, i.e., quicker early canopy establishment and greater interception during the whole growth period. Understanding the canopy architecture of maize is important for manipulating plant density for continuous maize improvement ${ }^{16,44,45}$. Compared to that under the CK, the maize plant growth under the N2D3 treatments presented $11.8-12.3 \%$ greater LAI values. Early and rapid canopy establishment allows maize to take advantage of higher IPAR pre-canopy closure ${ }^{46,47}$, where the greatest amount of radiation is available in June and July (Table 5). The greater LAI resulted in a greater fPAR, compared with that of the CK, and an 6.3-11.9\% increase in the fPAR was observed for the entire growth period in the N2D3 treatments (Fig. 4), as well as an increased in cumulative intercepted solar radiation for a similar growth period.

The RUE value determined in the present study ranged from 3.15 to $3.42 \mathrm{~g} \mathrm{MJ}^{-1}$, which was similar to values in the literature for maize in different parts of the world $\left(3.0-4.0 \mathrm{~g} \mathrm{MJ}^{-1}\right)^{48-51}$. Our results showed that dense 


\begin{tabular}{|l|l|l|l|l|l|}
\hline \multirow{2}{*}{ Planting treatments } & \multicolumn{3}{|l|}{ N rate and timing $\left(\mathbf{k g ~ h a}^{-1}\right)$} & \multicolumn{2}{l|}{ Planting density } \\
\cline { 2 - 7 } & Total & Basal & Top-dressed & Spacing $(\mathbf{c m})$ & Plant number $\left(\right.$ plant ha $\left.^{-1}\right)$ \\
\hline N1D1 (CK) & 240 & 120 & 120 & $60.0 \times 24.6$ & 67,500 \\
\hline N1D2 & 240 & 120 & 120 & $60.0 \times 21.5$ & 77,500 \\
\hline N1D3 & 240 & 120 & 120 & $60.0 \times 19.0$ & 87,750 \\
\hline N2D1 & 204 & 84 & 120 & $60.0 \times 24.6$ & 67,500 \\
\hline N2D2 & 204 & 84 & 120 & $60.0 \times 21.5$ & 77,500 \\
\hline N2D3 & 204 & 84 & 120 & $60.0 \times 19.0$ & 87,750 \\
\hline
\end{tabular}

Table 6. $\mathrm{N}$ fertilization application and planting density for each planting treatments.

planting combined with a $15 \%$ reduced $\mathrm{N}$ rate resulted in lower RUE that was lower than that of the CK. The main reason for the effects of planting treatment on maize RUE was the vertical distribution of the $P_{A R}$ in the lower canopy layer. In the present study, both the absolute value of the LAI (Fig. 3) and the amount of PAR captured (Fig. 5) in the upper canopy layer under the N2D3 treatment was greater than those under the CK, which led to poor light distribution through the canopy (higher $k$ ), and relatively more light captured by the upper canopy has been suggested to reduce the whole plant photosynthetic efficiency, which in turn decreases the RUE ${ }^{52,53}$. Because a larger fraction of shaded leaves may lead to a higher ineffective photosynthetic area and canopy respiratory consumption, the whole canopy conversion efficiency is reduced especially at a high LAI. As a result, the N2D3 treatment had a relatively lower RUE.

Excessive $\mathrm{N}$ applied at the basal time is the main constraint on the crop NUE under conventional planting practices in China ${ }^{54,55}$. Dense planting with a reduced $\mathrm{N}$ rate was believed to improve not only grain yield but also $\mathrm{N}$ use efficiency ${ }^{7,30,56}$. In our present study, reduced basal $\mathrm{N}$ input significantly increased NPFP compared to CK (Fig. 1). A reduction in basal $\mathrm{N}$ application could significantly reduce $\mathrm{N}$ loss during the lower demand early growth stage of maize seedlings ${ }^{54,57}$. The results from this study suggest that both higher yield and NUE may be achieved in maize production by optimizing $\mathrm{N}$ application and density interaction management practices.

From the perspective of our study, improvement of radiation interception through producing a reasonable canopy structure is an effective strategy for enhancing crop yields (Fig. 7). As such, increasing the planting density is a suitable agronomic practice for manipulating the structure of the population and canopy. Thus, increasing density is recommended to further increase grain yields. In our environment, a poor RUE was detected in the high density treatments. Furthermore, agronomic measures (e.g., row spacings, canopy types, use of growth regulators) should be optimized to synchronously increase the IPAR and the RUE ${ }^{15,45,58-60}$. Moreover, reducing the amount of $\mathrm{N}$ applied is recommended to improve $\mathrm{N}$ use efficiency, as excessive $\mathrm{N}$ input is very common in the country ${ }^{54}$. Our results indicate that increasing planting density combined with less basal $\mathrm{N}$ input can be a good technique for high-yield and environmentally friendly maize cropping in the Huanghuaihai Plain maize region in China.

\section{Conclusions}

This study demonstrates that high maize grain yield and high NUE could be simultaneously achieved by $30 \%$ increase in planting density combined with a $15 \%$ reduction in the basal $\mathrm{N}$ applied. Increased grain yields were associated with increased sink capacity, and increased radiation capture was the primary factor responsible for the high productivity. In conclusion, it is possible and sustainable to maintain high grain yields with a reduction in basal $\mathrm{N}$ fertilization by increasing plant density in maize cropping systems in the Huanghuaihai Plain maize region in China.

\section{Materials and methods}

Experimental site. Field experiments were conducted in 2017 and 2018 at the experimental station of the Crop Research Institute, Anhui Academy of Agricultural Sciences ( $\left.33^{\circ} 11^{\prime} \mathrm{N}, 116^{\circ} 86^{\prime} \mathrm{E}\right)$ in Huaiyuan County, Anhui Province, China. The soil type or the field is a Shajiang black soil. Soil samples from the 0 to $20 \mathrm{~cm}$ soil layer were taken before fertilizer application during each growing season at the beginning of the field experiments. The organic matter (via the $\mathrm{K}_{2} \mathrm{Cr}_{2} \mathrm{O}_{7}-\mathrm{H}_{2} \mathrm{SO}_{4}$ oxidation method), total $\mathrm{N}$ (via the Kjeldahl method), available phosphorus (via the Olsen method), and available potassium (according to the ammonium acetate extraction method) in the top $20 \mathrm{~cm}$ of the soil were $25.7 \mathrm{~g} \mathrm{~kg}^{-1}, 1.6 \mathrm{~g} \mathrm{~kg}^{-1}, 17.9 \mathrm{mg} \mathrm{kg}^{-1}$, and $159.3 \mathrm{mg} \mathrm{kg}^{-1}$ in 2017 and $27.3 \mathrm{~g} \mathrm{~kg}^{-1}, 1.6 \mathrm{~g} \mathrm{~kg}^{-1}, 18.6 \mathrm{mg} \mathrm{kg}^{-1}$, and $168.4 \mathrm{mg} \mathrm{kg}^{-1}$ in 2018 , respectively. Daily records of the meteorological data, including the solar radiation, temperature and rainfall, were obtained from a weather station located adjacent to the experimental field. Daily incident PAR $(400-700 \mathrm{~nm})$ was calculated as $50 \%$ of the total daily solar incident radiation ${ }^{61}$. A summary of the monthly environmental meteorological data during the maize growing seasons in 2017 and 2018 was listed in Table 5.

Experimental design and field management. The field experiment plots were arranged in a split plot design with three replicates. The main plots were assigned to two $\mathrm{N}$ fertilization treatments (N1: $240 \mathrm{~kg} \mathrm{ha}^{-1}$ and N2: $204 \mathrm{~kg} \mathrm{ha}^{-1}$ ), and subplots were assigned to three planting densities (D1: 67,500 plants ha ${ }^{-1}, \mathrm{D} 2$ : 77,625 plants ha $\mathrm{h}^{-1}$ and D3: 87,750 plants ha $\left.{ }^{-1}\right)$. The size of each plot was $10.0 \times 7.2 \mathrm{~m}(12$ rows spaced $60 \mathrm{~cm}$ apart). The conventional high $\mathrm{N}$ rate combined with a low density planting management practice (N1D1) for 
high yield as control (CK). The spacing between plants within a row depended on the plant density. Phosphate (superphosphate, $12 \% \mathrm{P}_{2} \mathrm{O}_{5}$ ) and potassium (potassium sulfate, $60 \% \mathrm{~K}_{2} \mathrm{O}$ ) fertilizers were applied as a basal fertilizer at 90 and $120 \mathrm{~kg} \mathrm{ha}^{-1}$, respectively. For the N1 treatments, N (urea, 46.4\% N) was applied as a basal fertilizer at $120 \mathrm{~kg} \mathrm{ha}^{-1}$ before sowing and top-dressed at the V8 stages at a rate of $120 \mathrm{~kg} \mathrm{ha}^{-1}$. For the $\mathrm{N} 2$ treatments, $\mathrm{N}$ (urea, $46.4 \% \mathrm{~N}$ ) was applied as a basal fertilizer at a rate of $84 \mathrm{~kg} \mathrm{ha}^{-1}$ before sowing and then top-dressed at the V8 stages at $120 \mathrm{~kg} \mathrm{ha}^{-1}$. Detailed information about the $\mathrm{N}$ application rates and timing and planting density is listed in Table 6.

The cultivar Zhengdan 958 which is widely grown in the Huanghuaihai Plain maize region in China, was used $^{62}$. The previous crop grown in the field was winter wheat. After the harvest of the winter wheat, the fields were prepared with a rotary tiller to till the soil to a depth of $15 \mathrm{~cm}$ for maize sowing. The maize seeds were hand-planted, with two seeds per hill, on 8 June 2017 and 11 June 2018, respectively. The seedlings were then thinned to one seedling per hill to maintain the desired plant densities at 10 days after emergence. Crop management was in accordance with local high-yield cultural practices. There was no significant difference in the crop development (e.g., time of anthesis and black layer maturity) between the planting treatments. Maize was harvested on 30 September and 29 September 2017 and 2018, respectively.

Sampling and measurements. Plant biomass and $N$ analysis. Five maize plant samples per plot were collected at 15-day intervals from 25 June to 30 September 2017 and from 23 June to 25 September 2018. The sampled maize plants were cut at the soil surface and separated into leaves, stems and ear shoot components. The dry weight of each component was determined after drying for $72 \mathrm{~h}$ at $80^{\circ} \mathrm{C}$ in a forced-air drying oven. The plant samples were then milled, and the $\mathrm{N}$ concentration was analyzed based on the Kjeldahl method ${ }^{63}$. $\mathrm{N}$ uptake was calculated by multiplying the $\mathrm{N}$ concentration by the dry weight. The $\mathrm{NHI}$ was calculated as the $\mathrm{N}$ uptake in the grain divided by the total $\mathrm{N}$ accumulation in aboveground plants. $\mathrm{N}$ use efficiency was defined as the $\mathrm{N}$ partial factor productivity (NPFP), which was determined by the grain yield per unit of $\mathrm{N}$ applied $\left(\mathrm{kg} \mathrm{kg}^{-1}\right)$.

Leaf area index. The green LAI of the plant population for vertical canopy layers (e.g., soil surface, two leaves below the ear, two leaves above the ear, and $0.1 \mathrm{~m}$ above the maize canopy) was measured on the plant sample times. Lamina legth (L) and maximum lamina width (W) were recroded and leaf area (A) was calculated using the following equation:

$$
\mathrm{A}=0.75 \times L \times W,
$$

LAI was calculate as the sum of the areas of green leaves per unit area of land by plants ${ }^{64}$.

Determination of photosynthetically active radiation. The PAR was measured at different vertical canopy layers (e.g., at the soil surface, two leaves below the ear, two leaves above the ear, and $0.1 \mathrm{~m}$ above the maize canopy) in each plot using a SunScan Canopy Analysis System at noon on clear days. At least five readings of photosynthetic photon flux density were taken at each layer. The line quantum sensor was held in different directions but always parallel to the earth's surface. The data were recorded in 15-day intervals from 25 June to 19 September, 2017 and from 23 June to 20 September, 2018.

Radiation capture and radiation use efficiency. The fraction of photosynthetically active radiation (fPAR) of each treatment was then calculated using the following formula:

$$
f P A R=1-\frac{P A R_{b}}{P A R_{a}},
$$

where $\mathrm{PAR}_{\mathrm{a}}$ and $\mathrm{PAR}_{\mathrm{b}}$ are the above- and below-canopy PAR, respectively. The values of the $f \mathrm{PAR}$ for each day were estimated by fitting polynomial functions between the measured $f$ PAR and days after emergence ${ }^{43,65}$.

The IPAR intercepted ( $\Sigma$ IPAR) between two measurements was calculated using the following equation ${ }^{66}$ :

$$
\sum \mathrm{IPAR}=\Omega \times 0.5 \times f P A R_{d},
$$

where $\Omega$ is the summation of the total daily incident solar radiation between the investigation periods and $f \mathrm{PAR}_{\mathrm{d}}$ is the daily fraction of PAR interception during the investigation periods.

The RUE $\left(\mathrm{g} \mathrm{MJ}^{-1}\right)$ was calculated by dividing the total biomass $\left(\mathrm{g} \mathrm{m}^{-2}\right)$ by the cumulative IPAR $\left(\mathrm{MJ} \mathrm{m}^{-2}\right)$ during the growth period as follows ${ }^{43}$ :

$$
\mathrm{RUE}=\frac{\text { Biomass }}{\text { IPAR }}
$$

Yield and yield components. At maturity, plants within a quadrate $2.0 \mathrm{~m}$ long and $1.2 \mathrm{~m}$ wide (in the middle two rows) in each plot were harvested by hand to determine the grain yield in both seasons. Ears per square and kernels per ear were counted, and kernel numbers per square were determined. The thousand-kernel weight and grain moisture content were determined, and the yield was adjusted for $14.0 \%$ grain moisture content. The HI was calculated based on the grain yield and the total aboveground plant biomass at maturity. 
Statistical analysis. The data were statistically analyzed using SPSS 20.0 statistical software. The data are presented as the means \pm standard errors. Figures were then constructed using Origin 2018 software.

Received: 3 September 2020; Accepted: 10 December 2020

Published online: 11 January 2021

\section{References}

1. Gandhi, V. P. \& Zhou, Z. Food demand and the food security challenge with rapid economic growth in the emerging economies of India and China. Food Res. Int. 63, 108-124 (2014).

2. FAO. Food and Agriculture Organization of the United Nations Network. http://www.fao.org/faostat/en/\#data (2019). Accessed 3 Mar 2020.

3. Abera, T., Debele, T. \& Wegary, D. Effects of varieties and nitrogen fertilizer on yield and yield components of maize on farmers field in mid altitude areas of Western Ethiopia. Int. J. Agron. 3, 1-13 (2017).

4. Ning, P., Yang, L., Li, C. J. \& Fritschi, F. B. Post-silking carbon partitioning under nitrogen deficiency revealed sink limitation of grain yield in maize. J. Exp. Bot. 69, 1707-1719 (2018).

5. Shi, D. Y. et al. Increased plant density and reduced $\mathrm{N}$ rate lead to more grain yield and higher resource utilization in summer maize. J. Integr. Agric. 15, 2515-2528 (2016).

6. Wei, S. L. et al. Interaction of nitrogen fertilizer rate and plant density on grain yield and nitrogen use efficiency of maize. J. Plant Nutr. Fertil. 25, 382-391 (2019).

7. Zhu, X. C., Zhang, J., Zhang, Z. P., Deng, A. X. \& Zhang, W. J. Dense planting with less basal nitrogen fertilization might benefit rice cropping for high yield with less environmental impacts. Eur. J. Agron. 75, 50-59 (2016).

8. Chen, G. F. et al. Factors affecting nitrogen use efficiency and grain yield of summer maize on smallholder farms in the North China Plain. Sustainability 10, 363 (2018).

9. Yong, T. W. et al. Optimized nitrogen application methods to improve nitrogen use efficiency and nodule nitrogen fixation in a maize-soybean relay intercropping system. J. Integr. Agric. 17, 664-676 (2018).

10. Zhang, X. et al. Agricultural sustainable intensification improved nitrogen use efficiency and maintained high crop yield during 1980-2014 in northern China. Sci. Total Environ. 596-597, 61-68 (2017).

11. Zhang, Y. T. et al. Optimizing the nitrogen application rate for maize and wheat based on yield an environment on the Northern China Plain. Sci. Total Environ. 618, 1173-1183 (2018).

12. Jahan, M., Mahallati, M. N., Amiri, M. B. \& Ehyayi, H. R. Radiation absorption and use efficiency of sesame as affected by biofertilizers inoculation in a low input cropping system. Ind. Crop. Prod. 43, 606-611 (2013).

13. Boomsma, C. R., Santini, J. B., Tollenaar, M. \& Vyn, T. J. Maize morph physiological responses to intense crowding and low nitrogen availability: An analysis and review. Agron. J. 101(6), 1426 (2009).

14. Zhang, W. J. On the cultivation approach to green improvement of maize yield and $\mathrm{N}$ use efficiency in China: Dense planting with less N fertilizer. Crops 4, 1-4 (2015) (in Chinese with English abstract).

15. Li, S. K. et al. Technology and benefit analysis of high yield record field in maize. Crops 6, 1-6 (2017) (in Chinese with English abstract).

16. Seyoum, S., Rachaputi, R., Fekybelu, S., Chauhan, Y. \& Prasanna, B. Exploiting genotype $\times$ environment $\times$ management interactions to enhance maize productivity in Ethiopia. Eur. J. Agron. 103, 165-174 (2019).

17. Ciampitti, I. A. \& Vyn, T. J. A comprehensive study of plant density consequences on nitrogen uptake dynamics of maize plants from vegetative to reproductive stages. Field Crops Res. 121, 2-18 (2011).

18. Ming, B. et al. Changes of maize planting density in China. Sci. Agric. Sin. 50, 1960-1972 (2017).

19. Meng, Q. F. et al. Understanding production potentials and yield gaps in intensive maize production in China. Field Crops Res. 143, 91-97 (2013).

20. Liu, G. Z. et al. Nitrogen uptake and response to radiation distribution in the canopy of high-yield maize. Crop Sci. 59(3), 1236-1247 (2019).

21. Tian, J. D. et al. Teosinte ligule allele narrows plant architecture and enhances high-density maize yields. Science 365, 658-664 (2019).

22. Cheng, Y. et al. Modified fertilization management of summer maize in northern China improves grain yield and efficiency of nitrogen use. J. Integ. Agric. 14, 1644-1657 (2015).

23. Wei, S. S., Wang, X. Y., Zhu, Q. C., Jiang, D. \& Dong, S. T. Optimizing yield and resource utilization of summer maize under the conditions of increasing density and reducing nitrogen fertilization. Sci. Nat. 104, 86 (2017).

24. Zhai, L. C., Xie, R. Z., Ming, B., Li, S. K. \& Ma, D. L. Evaluation and analysis of intraspecific competition in maize: A case study on plant density experiment. J. Integr. Agric. 17, 2235-2244 (2018).

25. Zhang, G. et al. Optimizing planting density to improve nitrogen use of super high-yield maize. Agron. J. https://doi.org/10.1002/ agj2.20334 (2020).

26. Davidson, E. A., Suddick, E. C., Rice, C. W. \& Prokopy, L. S. More food, low pollution (Mo Fo Lo Po): A grand challenge for the 21st century. J. Environ. Qual. 44, 305-311 (2015).

27. Pareja-Sánchez, E., Plaza-Bonilla, D., Álvaro-Fuentes, J. \& Cantero-Martínez, C. Is it feasible to reduce tillage and N use while improving maize yield in irrigated Mediterranean agro ecosystems?. Eur. J. Agron. 109, 125919 (2019).

28. Dai, J. L. et al. Manipulation of dry matter accumulation and partitioning with plant density in relation to yield stability of cotton under intensive management. Field Crops Res. 180, 207-215 (2015).

29. Li, Y. et al. Plant density effect on grain number and weight of two winter wheat cultivars at different spikelet and grain positions. PLoS ONE 11(5), e0155351 (2016).

30. Huang, M., Chen, J., Cao, F. \& Zou, Y. Increased hill density can compensate for yield loss from reduced nitrogen input in machine transplanted double-cropped rice. Field Crops Res. 221, 333-338 (2018).

31. Sinclair, T. R. \& Muchow, R. C. Radiation use efficiency. Adv. Agron. 65, 215-265 (1999).

32. Shah, S. F. A., McKenzie, B. A., Gaunt, R. E., Marshall, J. W. \& Frampton, C. M. Effect of early blight (Alternaria solani) and different nitrogen inputs on radiation interception radiation use efficiency, and total dry matter production in potatoes (Solanum tuberosum) grown in Canterbury, New Zealand. New Zeal. J. Crop Hort. 32, 263-272 (2004).

33. Zahedi, M., Mondani, F. \& Eshghizadeh, H. R. Analyzing the energy balances of double-cropped cereals in an arid region. Energy Reps. 1, 43-49 (2015).

34. Chang, J. F., Zhang, H. H., Li, H. P., Dong, P. F. \& Li, C. H. Effects of different row spaces on canopy structure and resistance of summer maize. Acta Agron. Sin. 42, 104-112 (2016) (in Chinese with English abstract).

35. Geng, Y., Cao, G. \& Wang, S. Nitrogen accumulation characteristics of high-yield spring maize in Northeast China. Int. J. Plant Prod. https://doi.org/10.1007/s42106-018-0015-1 (2018).

36. Jiang, X. L. et al. Planting density affected biomass and grain yield of maize for seed production in an arid region of Northwest China. J. Arid Land 10(02), 292-303 (2018). 
37. Testa, G., Reyneri, A. \& Blandino, M. Maize grain yield enhancement through high plant density cultivation with different inter row and intra-row spacings. Eur. J. Agron. 72, 28-37 (2016).

38. Keating, B. A. \& Carberry, P. S. Resource capture and use in intercropping: Solar radiation. Field Crops Res. 34, 73-301 (1993).

39. Luque, S. F., Cirilo, A. G. \& Otegui, M. E. Genetic gains in grain yield and related physiological attributes in Argentine maize hybrids. Field Crops Res. 95, 383-397 (2006).

40. Amanullah, M., Nawab, K. \& Ali, A. Response of specific leaf area (SLA), leaf area index (LAI) and leaf area ratio (LAR) of maize (Zea mays L.) to plant density, rate and timing of nitrogen application. World Appl. Sci. J. 2, 235-243 (2007).

41. Maddonni, G. A. \& Otegui, M. E. Leaf area, light interception, and crop development in maize. Field Crops Res. 48(1), 81-87 (1996).

42. Maddonni, G., Otegui, M. \& Cirilo, A. Plant population density, row spacing and hybrid effects on maize canopy architecture and light attenuation. Field Crops Res. 71(3), 183-193 (2001).

43. Du, X. B., Chen, B. L., Shen, T. Y., Zhang, Y. X. \& Zhou, Z. G. Effect of cropping system on radiation use efficiency in double cropped wheat-cotton. Field Crops Res. 170, 21-31 (2015).

44. Ku, L. X. et al. Integrated multiple population analysis of leaf architecture traits in maize (Zea mays L.). J. Exp. Bot. 63(1), 261-274 (2011).

45. Battaglia, M., Lee, C., Thomason, W. \& Mullekom, J. V. Effects of corn row width and defoliation timing and intensity on canopy light interception. Crop Sci. 59(4), 1718-1731 (2019).

46. Zhu, X. G., Long, S. P. \& Ort, D. R. Improving photosynthetic efficiency for greater yield. Annu. Rev. Plant Biol. 61, 235-261 (2010).

47. Parry, M. A. J. et al. Raising yield potential of wheat. II. Increasing photosynthetic capacity and efficiency. J. Exp. Bot. 62, 453-467 (2011).

48. Bolanos, J. \& Edmeades, G. O. Eight cycles of selection for drought tolerance in lowland tropical maize. I. Responses in grain yield, biomass and radiation utilization. Field Crops Res. 31, 233-252 (1993).

49. Wang, Z. K. et al. Radiation interception and utilization by wheat/maize strip intercropping systems. Agric. For. Meteorol. 204, 58-66 (2015).

50. Gou, F. et al. Intercropping wheat and maize increases total radiation interception and wheat RUE but lowers maize RUE. Eur. J. Agron. 84, 125-139 (2017).

51. Parihar, C. M. et al. Soil water dynamics, water productivity and radiation use efficiency of maize under multi-year conservation agriculture during contrasting rainfall events. Field Crops Res. 241, 107570 (2019).

52. Sadras, V. O. Population-level compensation after loss of vegetative buds: Interactions among damaged and undamaged cotton neighbors. Oecologia 106, 417-423 (1996).

53. Yao, H. S., Zhang, Y. L., Yi, X. P., Zhang, X. J. \& Zhang, W. F. Cotton responds to different plant population densities by adjusting specific leaf area to optimize canopy photosynthetic use efficiency of light and nitrogen. Field Crops Res. 188, 10-16 (2016).

54. Peng, S. et al. Strategies for overcoming low agronomic nitrogen use efficiency in irrigated rice systems in China. Field Crops Res. 96, 37-47 (2006).

55. Du, X. B., Kong, L. C., Xi, M. \& Zhang, X. Y. Split application improving sweetpotato yield by enhancing photosynthetic and sink capacity under reduced nitrogen condition. Field Crops Res. 238, 56-63 (2019).

56. Tian, G. et al. Improving rice population productivity by reducing nitrogen rate and increasing plant density. PLoS ONE 12, e0182310 (2017).

57. Yang, G. Z., Tang, H. Y., Nie, Y. C. \& Zhang, X. L. Responses of cotton growth, yield, and biomass to nitrogen split application ratio. Eur. J. Agron. 35, 164-170 (2011)

58. Mao, L. L. et al. Crop growth, light utilization and yield of relay intercropped cotton as affected by plant density and a plant growth regulator. Field Crops Res. 155, 67-76 (2014).

59. Liu, G. Z. et al. Canopy characteristics of high-yield maize with yield potential of $22.5 \mathrm{Mg} \mathrm{ha}^{-1}$. Field Crops Res. 213, 221-230 (2017).

60. Lu, Y. et al. Increasing the planting uniformity improves the yield of summer maize. Agron. J. 109(4), 1463-1475 (2017).

61. Monteith, J. L. \& Unsworth, M. Principles of Environmental Physics 2nd edn. (Eaward Arnold, London, 1990).

62. Zhang, S. et al. Testing the suitability of the end-of-season stalk nitrate test for summer corn (Zea mays L.) production in China. Field Crops Res. 154, 153-157 (2013).

63. Horowitz, W. Official Methods of Analysis 11th edn, 17-18 (AOAC, Washington, 1970).

64. Muchow, R. C. \& Carberry, P. S. Environmental control of phenology and leaf growth in tropically-adapted maize. Field Crops Res. 20, 221-236 (1989).

65. Van Opstal, N. V., Caviglia, O. P. \& Melchiori, R. J. M. Water and solar radiation productivity of double-crops in a humid temperature area. Aust. J. Crop Sci. 5, 1760-1766 (2011).

66. Awal, M. A. \& Ikeda, T. Effect of elevated soil temperature on radiation-use efficiency in peanut stands. Agric. Forest Meteorol. 118, 63-74 (2003).

\section{Acknowledgements}

This research was supported by Grants from the National Key Research and Development Program of China (Nos. 2018YFD0300902, 2017YFD0301306).

\section{Author contributions}

X.B.D. and L.C.K. conceived and designed the experiment. X.B.D. performed the experiments and analyzed the data. X.B.D. wrote the manuscript. X.B.D., Z.W., W.X.L. and L.C.K. revised the manuscript. All authors discussed the results and approved the manuscript.

\section{Competing interests}

The authors declare no competing interests.

\section{Additional information}

Correspondence and requests for materials should be addressed to X.D. or L.K.

Reprints and permissions information is available at www.nature.com/reprints.

Publisher's note Springer Nature remains neutral with regard to jurisdictional claims in published maps and institutional affiliations. 
(c) (i) Open Access This article is licensed under a Creative Commons Attribution 4.0 International cc) License, which permits use, sharing, adaptation, distribution and reproduction in any medium or format, as long as you give appropriate credit to the original author(s) and the source, provide a link to the Creative Commons licence, and indicate if changes were made. The images or other third party material in this article are included in the article's Creative Commons licence, unless indicated otherwise in a credit line to the material. If material is not included in the article's Creative Commons licence and your intended use is not permitted by statutory regulation or exceeds the permitted use, you will need to obtain permission directly from the copyright holder. To view a copy of this licence, visit http://creativecommons.org/licenses/by/4.0/.

(C) The Author(s) 2021 